\title{
Planting Aesthetics Seeds within the Journey of Children's Reading
}

\author{
Jui-Ching Cheng ${ }^{1}$, Siou-Mi Chen ${ }^{2}$, Mei-Ju Chou ${ }^{3, *}$ \\ ${ }^{1}$ Department of Early Childhood Education, National Pingtung University, Taiwan \\ ${ }^{2}$ Da-Huah Elementary School, Kaohsiung, Taiwan \\ ${ }^{3}$ Department of Early Childhood Education \& Center for Teacher Education, National Pingtung University, Taiwan
}

Copyright (C) 2015 by authors, all rights reserved. Authors agree that this article remains permanently open access under the terms of the Creative Commons Attribution License 4.0 International License

\begin{abstract}
For the impact of parent-child reading picture books have on the child's learning process has been recommended at the elementary level as the appropriate strategies to bridge preschool and family education. The purpose of the study is firstly, to investigate the key virtues of the implementation in children's reading in preschool and at home; secondly, in terms of the challenges encountered to propose appropriately efficient solutions; thirdly, to enforce teachers' self-fulfillment and confidence in promoting young children's reading. Qualitative data were collected through observations, interviews, recording of anecdotes, adults' feedback sharing, and reflective journals from four projects, including advocating parent-child reading, inspiring young children's motivations to read, enhancing young children's interactions with picture books, and reading is funny. Data analysis included the sound and video records from teaching process, book list for learners, parents' sharing, teachers' sharing, researchers introspection daily, interviewing kids. According to these qualitative data, researchers adopted triangulation strategy to encode the data collected on the scene one by one. The results revealed four elements contributing in successful reading-extension activity, including environmental settings, appropriately developed activities during parent-child reading, the educators' scaffolding, and the educators' fulfillment in growth and self-professionalism. A last, the practical suggestions and possible directions for young children reading were proposed for the institute, preschool, educators and parents of early childhood education.
\end{abstract}

Keywords Young Children, Parent-child Reading, Picture Books, Reading-extension

\section{Introduction}

Educators' instruction for students' gaining the recent knowledge will guide them pass the test of tomorrow; however, the instruction for cultivating students how to learn will guide them to pass the test for the whole life learning. (Essa, 2012) [1]

Since August of 2000, the K-12 Education Administration, Ministry of Education proposed a three-year term "Nation Reading Initiative," to the time former Minister of Education Ovid Tzeng in his office, fully supported relevant reading policy till now, there has not shown a significant result. In 2006, there was a study on promoting worldwide reading literacy: it targets on the fourth grade students in primary schools among 45 countries. Taiwan was ranked $22^{\text {th }}$, but students' wills to read did not end up being more active. Since over the 1 2 years, statistic numbers tell us, among Four Asian Dragons, citizens in Taiwan have the worst intention on reading. We wondered what happened to our education? Possibly due to the stress given by the whole selective education system, students keep running away from positive learning. Research (Apple[2], 2013; Hallinger[3], 2010; Heisey \& Kucan[4], 2010; Postman[5], 2011; Race[6], 2014) proposed that the modern education seems pushing children to cram up contents from books, though they are not interesting. Maybe due to the lack of guidance, children cannot make emotion with context and being touched, inspired or motivated by reading. They can't understand the idea by ancient people: "There are fortunes and mates of soul in books." No matter what, in the future seeking a way to let people love reading or cultivate them with good reading habit will be an important issue. Education Bureau (2008 [7]; 2012[8]) proposed the importance of reading for young children. Therefore, the research aims to explore the planting reading seed for children in preschool and at home. Further, with the bridge between early childhood and family education, the research plans to find out appropriate instruction which is beneficial to educators' broadening self-professional knowledge. The American educationist Dewey (2005)[9] once said, "Education is living." Bloom (2010)[10] also pointed out that, education is just a process, and in every phase of the process should be applied with a suitable education. The father of early childhood education, 
Froebel said: "If you grew a habit very easily in childhood, it is going to be very hard to quit it" (Beck, McKeown, \& Kucan, 2012[11]). It tells us the importance of early childhood education. Daisy L. Hung, the educationalist who keeps promoting reading nationwide, always advocates to let people read more no matter during her period of publishing new books or speeches through illustrating advantages of reading.

Concerning the actively building an environment for motivating children to read actively and with skillful strategy, "quantity can be equal to quality" serves as the principle for adults scaffolding. Children can learn the way to solve problem from reading, and through impersonation, recognition, literature has the imperceptible influence in cultivating children development in language, recognition, social, emotional, aesthetics and quality character (Bruce, 2012[12]; Carlson, etc, 2008[13], ; Early, etc. 2007[14]; Mol, $\&$ de Jong, 2009[15]). Based on above research motivations, the purposes of this study are the followings:

1 . To explore the process and efficiency of promoting reading to children

2. To explore the educators' self-fulfillment in guiding children reading

\section{Literature Review}

Parent-child Reading

Perhaps you own unlimited wealth

Many boxes of jewels and gold

But you will never be richer than me

I have a mother who reads to me

_From Strickland Gillilan

Research (James\& Prout, 2015[42]) revealed the significance of parent-child reading have aroused preschool education attention. As the role of parents gradually become the first two significant instructors for children before their preschool period, in modern high-technology knowledge society, parents' educational or occupational backgrounds are not the most important things; Instead, parents' setting up examples for children's learning would be more important than the traditional times. If parents can be more involved in interacting with kids while reading, such as proposing more questions, constructing conversations with kid, appraising, adding information to the story topic, discussing possible thoughts, sharing experiences, all of those actions can potentially cultivate child's interest and skill of reading in the earlier period (Kindle, 2011[16]; Lonigan \& Shanahan, 2010[17]). Further, while adults and children are reading together, the discussion between them can be transformed from visual metaphors to the bridge of seeking its meaning within reading stories or picture books (Willett, Robinson, \& Marsh, 2009[18]; Wasik \& Bond, 2009[19]; McGee \& Richgels, 2008[20]).

Further, many literatures prove that "parent-child reading" is one essential factor in contributing educating a child, since it not only causes the following benefits to child's growth (Justice, 2002[21]), but also leads to positive development in language, recognition, social, emotional, aesthetics areas (Chou\& Lee, 2012[22]; Ko \& Chou, 2014[23]). Indeed, Parent-Child reading improves the relation between kids and parents (Kassow 2008[24],). Especially when the process of reading is pleasuring and open-ended, children will experience the fun of reading and grasp the aesthetics experience in reading and in their interactions with parents as well (Sansanelli \& Hustedt 2009[25]; Wohlwend, 2011[26]). Parent-child reading together directly enriches child's auditory comprehension of vocabulary (Belland etc. 2008[27]; Machado, 2010[30]); Reading with children establishes them more and complete understanding about reading (Lonigan \& Shanahan, 2010[17]). Summing up above results, we come to a conclusion that children's behavior is influenced by the parents. Therefore, to build children's interest in enjoying reading, parents must realize the concept of children's development, excite children's joyfulness in reading while the child is very young and while parents could arrange quality time in accompanying reading.

Specific Practices to Promote Parent-child Reading

Zucker (2009) [29] proposed that every cycle of reading always follow a certain process, including choosing books, reading, and having response, and those three elements make a interaction circle finally. It is noteworthy that in the concept of parent-child reading, there is a reading cycle of parents' interaction with the children toward reading into the deepest central figure - "trying to get the assistance from an adult of ability," not only helps children to build the reading habit but also create an appropriate environment of reading (Lonigan \& Shanahan, 2010[17]; Teale, Hoffman, \& Paciga, 2010[42]). According to previous parent-child reading experiences, we summarize several specific practices as the followings (Biemiller \& Boote, 2006[30]; Brabham \& Lynch-Brown, 2002[31]) including before, during, and after parent-child reading.

Before Parent-Child Reading:

1. Create a pleasant parent-child reading mood and interesting reading environment.

2. Encourage or reward way children to read with motivation and interests.

3. First time reading and choice of books within reading approach should be based on the child's interests and needs-based.

4. Before parent-child reading, adults should maintain a calm mind, instead of being angry, and absolutely cannot do any violence onto child.

\section{During Reading}

1. Beauchat, Blamey, \& Walpole (2009)[32] proposed that with the application of appropriate reading tone, rhythm, facial expression, and body language to transform variety way of reading techniques for children, children would love to read through parents' guiding from pictures to words, from interest to knowledge, from continuousness to habit-building. 
2. Parents guide children to read/explain from the cover page, including the name of the author and the illustrator, the publication of the book to the last page of the book, and explain to children that "the book is finished" for every time reading.

3. Parents lead children to use the fingers to point, and to turn to the next page while parents and children read together, and always give children opportunity in practicing turning pages (Belland, etc, 2008)[27].

4. Parents need to be patiently repeat reading, make proper pausing during reading, and making different story atmosphere.

5. Parents need to apply listening, speaking, reading, and writing four skills (Biemiller \& Boote, 2006)[30] to appreciate children's thoughts, thinking, and expression.

6. Young children learn from voices, if the child is too young, parents could make the child sit on the knees, and read loudly for the child.

\section{The Function of Parent-child Reading}

Reading is a complex multi-aspects course, children need a natural way to learn how to integrate these factors required among reading courses. Parents and teachers are the most direct mentor to kids. The followings are the multiple roles parents play in reading (Essa, 2012[1]; Heisey \& Kucan, 2010[4]): (A) Provider - with books resources, arrangements or provide reading environment. (B) Guide - parents are who know things and how to guide children to read books. (C) Sharer - parents share the mood, feelings and fun during reading. (D) Learner - parent learn how to read with their children, and wander around in the reading world together. During recent research, with reading for children came out with a huge influence, many scholars and experts also have also published their views on the advantage of parent-child reading. The common features of the function of reading are summarized as the followings:

\section{(A) Children's Development}

Research (Dickinson, Golinkoff, \& Hirsh-Pasek, 2010[33]) proposed that parent-child reading can balance emotions and personality development for children; Parent-child reading can not only enhance the cognitive level (Kim, 2008[34]) of function, in fact, it also reflects an emotional level in a parent-child relationship which is unique and irreplaceable. On the development of this theory, one of parent-child interactions is to help children to develop their self-concept (Lellemyr, 2009[35]), culture emotional maturity (Kindle, 2011[16]), personality (Morrow, Freitag \& Gambrell, 2009[36],) through daily life experience with parent-child reading.

\section{(B) Language Aesthetics}

With the process of parent-child language scaffolding and reading, it always brings children the simplest pleasures (Machado, 2010[28]; Vygotsky, 1978[37]). Further, Wasik\& Blewitt (2006) [38] proposed that the questioning style of parents' reading picture books to the children serves as the action of sowing the seeds through the most beautiful languages in general, when children listen adult to read these picture books, it is the greatest achievements of what a language can do for the children.

\section{(C) Modeling and Copying}

During children's curiosity and eager in learning period, children learn what they see, hear, say, and do from their interactions with parents. Thus, the parent-child reading is exemplary for daily life naturally cultivating children's personality, development, and life attitude. While the parents were reading, it naturally leads to insightful views that adults' accompany to child serves as the best teaching and demonstration examples, which elevate the inter-relationship between adults and parents. Tompkins (2007) [39]proposed that if a child falls in love with reading books in his childhood, the aesthetics of reading experience will not only maintain for being long-lasting good memories, but also cultivate children in positive life-long learning, motivate inner learning through his whole life. And this aesthetic experience will always be full of the children's mind and soul, just like to light and heat continuously immersing into children's learning energy. As Koshy (2010) [40] believed that via operating a home reading environment, parents can do the most of activities with children by reading or playing with children. Finally, Machado (2010) [28] revealed that in front of your kids, opening a book is to open a world for them. Cultivating children's interests in reading is equal to let them have a broader world.

\section{(D) Parent-child Reading Targets Not Only in Paternity of Society}

In terms of parent-child shared reading, it is not necessarily limited to parent and child, that being said, reading with grandparents and brothers or sisters can also be very good reading activity. Schickedanz\& McGee (2010) [41] proposed that even grandparents can have different interpretations of the story due to their different life experiences and journey. Through grandparent- child reading, it not only allows grandparents to enter into the inner world of children, but also grandparents can express their feelings to grandchildren (Teale, Hoffman, \& Paciga, 2010[42]). Also, as to reading together with brothers and sisters, it can be an object of worship, because of children's communication within stories, imagination and creativity easily embellish the story. Perhaps children's reading together is more influential than reading with their own parents.

\section{(E) Harmony Parent-Child Interrelationship}

Parent-child reading and listening based on a harmonious relationship leads to aesthetic experience for children, for parents, for teachers, and for grandparents. With the practical implementation for everyone, Bloom (2010) [10] proposed the significance of the process during parent-child shared reading as the followings: (1) Parent-child reading which 
focuses not on how much they read the book, but the two parties must have thoughts and feelings in the process, whether they enjoy the fun of reading altogether, and finally being thankful to each other's existence. (2) This warm, real feeling will always remain inside the hearts of children. (3) Time is what a life composes of, if children do feel the love from their parents' wills to share the happy time with them, adults have just given children the most irreplaceable gift.

\section{Relevant Researches on Promoting Early Childhood Reading}

Orville Prescott proposed that "Few children learn to actively love books by themselves. Someone must have led them into the wonderful magic world of literature. Someone has to show them the way."(James \& Prout, 2015[43]) With the goal of promoting children's reading, the following research proposed their related points of view.

From these researchers, the important direction from the literatures and a great strategy to promote reading was revealed:

(A) As to promoting reading in early childhood, parent-child reading is extremely important, indispensable, and capable to provide parents a clear reading conviction. (B) Illustrated picture books are the best medium to promote early childhood reading. (C) Reading is an interesting experience, but it needs guidance from teachers and parents, which is a key to reading successfully, cheerfully in children's hearts. Moreover, picture books bring up activities to promote parent-child reading to make children carry their own reading habits into the home. It can also inspire a child's post ability when children respond to questions via reading, parents' sharing, other teachers' sharing.

Table 1. Related Research on Preschool Reading

\begin{tabular}{|c|c|c|c|}
\hline Research & Topic & Method & $\begin{array}{r}\text { Findings } \\
\end{array}$ \\
\hline Lee $(2002)[44]$ & $\begin{array}{l}\text { Application of Stories on Children's } \\
\text { Leisure Activity }\end{array}$ & $\begin{array}{l}\text { Multiple Intelligence on } \\
\text { Instruction provides parents } \\
\text { correct reading belief }\end{array}$ & $\begin{array}{l}\text { Reading is a kind of leisure, a bridge between } \\
\text { children and adults. With the cooperation of } \\
\text { family and preschool, children would have an } \\
\text { appropriate learning environment. }\end{array}$ \\
\hline Liao (2003)[45] & $\begin{array}{l}\text { Promoting Parent-Child } r \text { Shared } \\
\text { Reading and Children's Reading } \\
\text { Behavior }\end{array}$ & $\begin{array}{l}\text { Design story and play for 5-6 } \\
\text { years old children to realize } \\
\text { children's reading } \\
\text { performance }\end{array}$ & $\begin{array}{l}\text { children's growth is as follows. From } \\
\text { discussing, active reading, to self-designing } \\
\text { stories, reading for others, and toward free } \\
\text { play, solving problem, and independent } \\
\text { reading makes parent-child reading quality. }\end{array}$ \\
\hline Huang (2004)[46] & $\begin{array}{l}\text { Elementary School Grade } 9 \text { students' } \\
\text { reading interests }\end{array}$ & $\begin{array}{l}\text { The promoting of children's } \\
\text { reading elevates children's } \\
\text { reading motivation }\end{array}$ & $\begin{array}{l}\text { Adults' scaffolding and guiding in resources is } \\
\text { necessary for children's reading. Children love } \\
\text { to read by themselves. }\end{array}$ \\
\hline Lin $(2004)[47]$ & $\begin{array}{l}\text { Reading Symposium-Exploration on } \\
\text { children's classroom reading and play }\end{array}$ & $\begin{array}{l}\text { How would children interpret } \\
\text { storybooks from play, singing, } \\
\text { painting, and arts. }\end{array}$ & $\begin{array}{l}\text { Reading itself is full of pleasure, and with } \\
\text { adults guidance, children's creative thinking } \\
\text { elevates reading. }\end{array}$ \\
\hline $\mathrm{Ko}(2006)[48]$ & $\begin{array}{l}\text { Promoting Parent-children Reading in } \\
\text { Preschools }\end{array}$ & $\begin{array}{l}\text { Research based on solving } \\
\text { problem for } 4-6 \text { years old } \\
\text { children }\end{array}$ & $\begin{array}{l}\text { Strategic application proposed direct efficiency } \\
\text { for children's reading and problem solving } \\
\text { ability. }\end{array}$ \\
\hline Luo (2011) [49] & Give me Five - enjoy reading & $\begin{array}{l}\text { Action research on solving } \\
\text { problem }\end{array}$ & $\begin{array}{l}\text { The internalization of knowledge needs to be } \\
\text { processed through children's daily life } \\
\text { experience. }\end{array}$ \\
\hline Liao (2008)[50] & $\begin{array}{l}\text { Exploration on Children's Practical } \\
\text { Reading }\end{array}$ & $\begin{array}{l}\text { The Verify of Theories and } \\
\text { Practices in Explaining the } \\
\text { Time and the Way Young } \\
\text { Children Read }\end{array}$ & $\begin{array}{l}\text { Build natural and aesthetic environment for } \\
\text { children would make children build good } \\
\text { learning basis and reading habit. }\end{array}$ \\
\hline Dun (2008) [51] & $\begin{array}{l}\text { Action Research on Preschool } \\
\text { Educators Reading Program }\end{array}$ & $\begin{array}{l}\text { Observation, Interviews, } \\
\text { Teaching Dairy, } \\
\text { Questionnaires, Children's } \\
\text { Works are the best resrouces. }\end{array}$ & $\begin{array}{l}\text { Aesthetic learning environment elevated adults } \\
\text { and children interrelationship and educators' } \\
\text { professionalism develpoment. }\end{array}$ \\
\hline Liao (2008) [52] & $\begin{array}{l}\text { How Would Preschool Educators } \\
\text { Build Children's Reading Habit }\end{array}$ & $\begin{array}{l}\text { Semi-construct interview, } \\
\text { observations into classroom, } \\
\text { and related literature. }\end{array}$ & $\begin{array}{l}\text { Parents' insistence in guiding children is the key } \\
\text { for children's variety reading habit cultivation }\end{array}$ \\
\hline $\operatorname{Lin}(2009)[53]$ & $\begin{array}{l}\text { Magic on Silent Reform--Parent Child } \\
\text { Reading }\end{array}$ & $\begin{array}{l}\text { Action Research includes } \\
\text { interviews, observations, } \\
\text { questionnaires, and } \\
\text { children's works. }\end{array}$ & $\begin{array}{l}\text { Teachers need to realize parent's needs, design } \\
\text { reading plans, diligently discuss with } \\
\text { colleagues, scholars, actively go into } \\
\text { community, and willingness to self-reflect. }\end{array}$ \\
\hline $\begin{array}{c}\text { Heisey \& } \\
\text { Kucan(2010)[4] }\end{array}$ & $\begin{array}{l}\text { Science concepts to primary students } \\
\text { through read alouds }\end{array}$ & $\begin{array}{l}\text { Reading aloud during } \\
\text { language course }\end{array}$ & $\begin{array}{l}\text { Reading aloud is positively related to children's } \\
\text { reading ability }\end{array}$ \\
\hline $\begin{array}{l}\text { Wohlwend } \\
(2011)[26]\end{array}$ & Playing their way into literacies & $\begin{array}{l}\text { Reading, writing, and } \\
\text { belonging in the classroom }\end{array}$ & $\begin{array}{l}\text { Children's playing combined with reading and } \\
\text { writing would elevate children's learning } \\
\text { motivation }\end{array}$ \\
\hline
\end{tabular}




\section{Research Methods}

In this study, there are three parts beautiful things related to reading happening during one year, the one is parent-child reading at home, the other is parents' reading pictures for children in preschool, and the other is the preschool teachers' self-fulfillment in professionalism reading journey. Therefore, reading picture books is deemed as the main media to promote a design-related education and outreach activities. The data collection includes observations, recording, videoing, questionnaires, children's works, and interviews for parents, children and preschool educators.

Participants in the study were 30 parent-child dyads (17 girls and 13 boys children of 60 months of age). Data were collected through home visits. Parent-child shared reading was observed and coded using an adapted version of the Adult-Child Interactive Reading Inventory (ACIRI). Parent-child interaction while playing with toys was also observed and coded using the Parenting Interactions with Children: Basic demographic information and the frequency of shared reading were obtained through a parent interview.
For the role of the researchers, we are not only practitioners, guider, but also observers, the subjective and objective ideas will be included for data collection for the research. In order to avoid excessive self's subjective consciousness, the research adopts continuous self-reflection on the $\log$ among researches. As to all discussion guide taught in schools, teachers share with parents how they respond, in order to achieve good educational objectives.

Concerning the "Spreading Aesthetic Seeds into Children's Reading Program," the process includes: (1) Problem Exploration: The Importance of Children's Reading, (2) Related Literature and Professors' Interview, (3) Setting for Research Plans. Plan A: Promoting Parents-Children Reading, Plan B: Motivating Children's Reading, Plan C: Advance Children's Interaction with Picture Books, Plan D: Reading is So Interesting, (4) Plan Implementation and Results Observation, (5) Reflection and Plans Adjustment,(6) Results Evaluation: Records, Interviews, Children's Works, Questionnaires, Teachers' Observation, Parents' Sharing and Feedback, and (7) Conclusion and Discussion.

The following is the research framework.

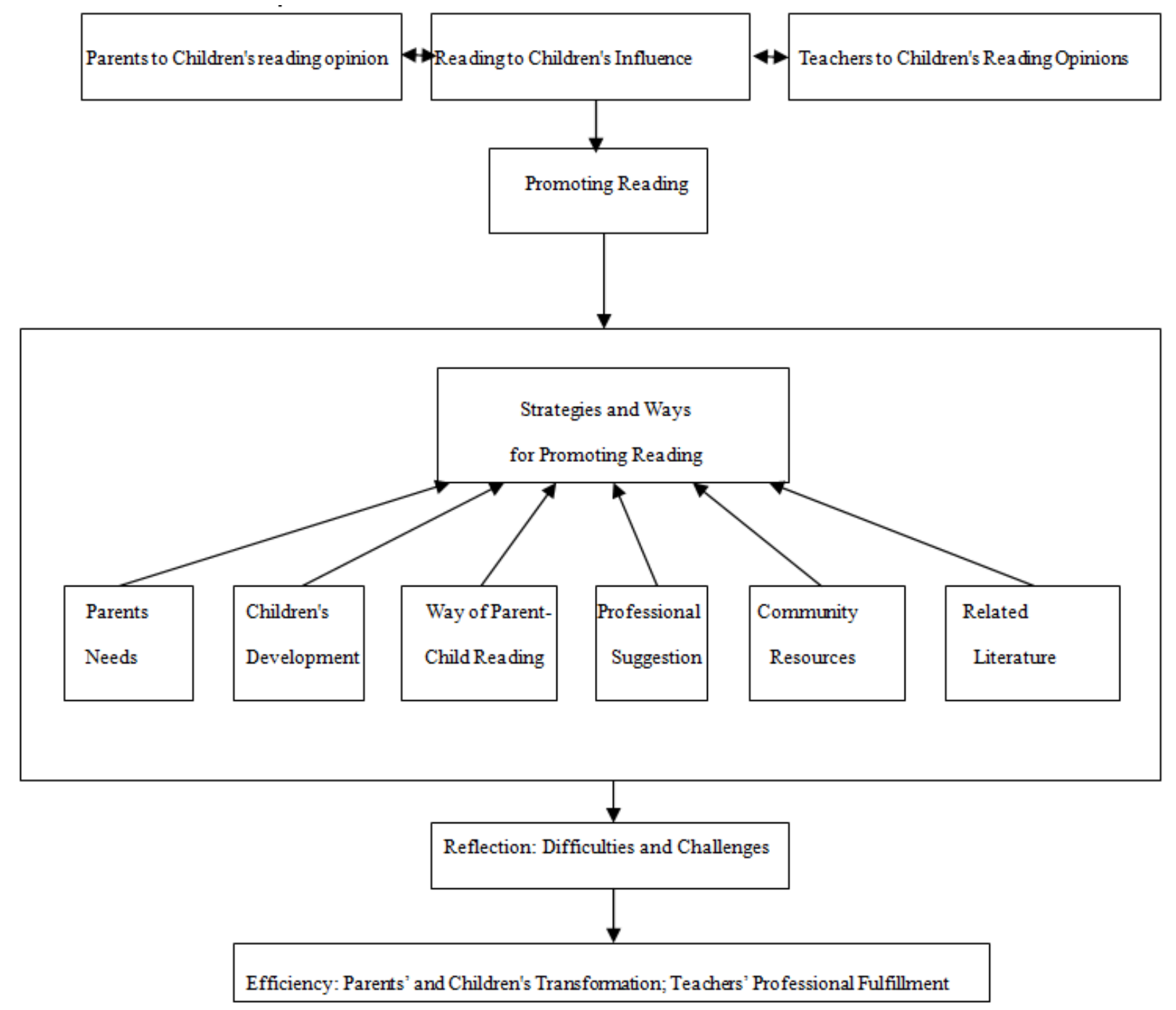




\section{Data Collection and Analysis}

\section{Data Collection}

In order to verify the consistence and validity of the research process, data triangulation skill is adopted for the collected data. For the data collection part, interviews, observation, video, recording, researchers' teaching diary, interviews are the sources for data collection. The research sampling adopts one preschool teacher and 30 children and their parents within one classroom in public preschool. The data includes the following, observation records, reading sheets, parents' and teachers' sharing sheets, a teaching daily for researchers, and interview records with children.

\section{Observation Records}

In order to grasp teaching actual situation, children's learning process, and the instruction situation derived from the interactions between teachers and learners, the researchers themselves put themselves into the teaching process. With classroom videoing and recording to gain the reality for data collection, teaching reflection, observation, teaching dairy are adopted for this research.

\section{Reading Learning Sheets}

There are two kinds of reading learning sheets, one is the "Reading is so interesting" learning sheet, which is guided by teachers for young children. The other one includes "Parent-Child Shared Reading Feedback" and "Top Reader" learning sheet, which could offer information for teachers to realize how often and in what way parents participate in parent-child shared reading at home.

\section{Parents' Sharing Sheet}

Researcher would love to share with parents' experience for their shared reading with young children at school or at home or at library. It not only provides teachers demands, suggestions, and ideas for promoting reading and for self-reflection teaching.

\section{Teacher Sharing Sheet}

To interview with teachers belongs to the most important element in the data collection for the research. Researchers would love to appropriately adjust the teaching in accordance with other preschool teachers experience sharing in their interacting with parents and with young children, which provide the basis for self-future teaching direction and reexamination for the goal in promoting reading activity.

\section{A Teaching Daily for Researcher}

The introspection daily for this study is a "miscellany of picture books".

Every time when there has been a picture-booked instruction, the researcher will record those important teaching situations in the introspection daily for such lesson.

\section{Interview Record with Children}

The interview data collected were mainly from objects of study among classes. I have interviewed three to six kids to understand their interests, favors about reading and what they often do in the kindergarten. The research aims to see if their activities in kindergarten are suitable for them, such as "Teaching Kids to Read", "Borrowing Books to Read", "Mom's Story Time", "Reading is Fun", "Masters of Reading", "Little Story Performers" and "Kid's Story Time".

\section{Data Analysis}

The sources of study data in this study include sound \& video records of teaching process, book list for learners, parents' sharing, teachers' sharing, researcher's introspection daily, interviewing kids. According to these qualitative data, researcher can encode the data collected on the scene one by one. Therefore, the researcher adopted triangulation, which would be applied on findings and reactions on data from parents, kids and teachers.

\section{Research Process}

In this study, the research process is implemented as the followings:

The first step would be finding problems: trough researcher's participations in various conferences, seminars and relevant professional \& advanced studies to let kids feel the importance of reading. However, the modern living environment which exposes our kids with many electronic devices has been affecting our kids, such as reducing their wills to read and their possibility to have more social interaction and will eventually impact their lingual developments. So the research is encouraged to contribute own efforts on promoting kids' reading.

Second, I processed literature reviews and interviewed with experts, where as the researcher, I obtained a deeper understanding and a more professional way on solving current problems.

Third, I set up my search projects, where in this study I have totally four projects and each one of them contains three to five implementation strategies.

Fourth, I implemented my research project and observed the result, while in the same time collected data and recorded the research process in order to benefit the afterward introspection and correcting my research projects.

During the period when I was introspecting and correcting my research projects, if I found any problem, I adjusted and corrected strategy and direction of the whole project. After that, I re-arrange the content of research projects until researchers agreed that the research purpose is achieved.

Finally, I evaluated the outcome of research projects and proposed conclusions, introspections and advices as a researcher via methods such as questionnaire, interview, introspection daily of teaching, parents' sharing and feedback

\section{Research Project and Strategy}

While the researcher is planning research project and 
strategy, it will be a long time of thinking, searching information and references. Therefore, considered level of parents' cooperation, availability and values, there were four projects and related strategies were determined.

\section{Project I Advocating Parent-Child Reading}

Teachers hold parent-teacher conference and advocate parent-child reading during the school learning time. The following activities are help in the research. 1. A Letter to Parents 2. Kid Master of Reading 3. Reading is Fun: Kids' Works 4. Booklist for Parent-child Reading 5. Building a Group of Mom Storytellers to Unify the Team Spirit for Class

\section{Project II Inspiring Young Children's Motivations to Read}

Firstly, environmental education would be adopted for the research, for the building aesthetic environment plays important factor in attracting young children and motivating them to read in the language corner; furthermore, it encourages young children to spend their time in the corner. While they share their reading experiences, appraise kids' reading to strengthen their confidence and encourage their reading behavior.

Secondly, we would like to enrich picture books in class, for it not only providing a space that kids can bring their picture books into the kindergarten in order to trigger a trend of reading, but also praising little masters of reading in the public.

Thirdly, we would encourage young children to share their reading experience and motivate parents to participate more by interesting methods such as parent-child reading in home, sharing picture books in kindergarten, recording picture books they had read in activities "Master of Reading", "Booklist of Parent-child Reading" and "Reading is Fun".

\section{Project III Enhancing Young Children's Interactions with Picture Books}

This project aims to enhance young children's opportunities and abilities to interact with picture books. It includes below three implementation strategies:

\section{Borrowing Books Every Week}

Every Friday, visit "Furry Library" and borrow two books once, instructing kids to use exclusive library cards for children and learn how to borrow and return books there, and increasing the quantity of books kids borrow there and build up their habits and senses of responsibility to take care and maintain those picture books.

\section{Discuss and Share Stories}

Through the process of discussing and sharing stories, firstly, it helps young children's logical thinking and abilities to solve problem. Secondly, it helps children to proposing open-ended questions, which cultivate children to think and make them dedicated to reading. Therefore, teachers had better design the questions first and adapt selves to changing circumstances where they teach, while learning how to record and introspect their teaching. Finally, as young children love to share their reading experiences, from their raising hands to reply questions from teachers or parents, they become involved in loving reading books, and in which it is a process of growing up and the main spirit of promoting children's reading.

\section{Making Mini Books}

Making mini books is a teacher approach which can integrate reading activities, and it combines the six fields within the new course outline "body movement, health, cognition, language, society, emotion and beauty" and three major skills: cognition, love and body skills. Under assistance and guilds from teachers, kids use various paper materials and art tools to make their own mini books to express personal styles and traits. With giving children opportunities to become storytellers of their own mini books, young children could publish their creativity, originality, and imagination from mini books they made in turns and the whole process turned out being very happy.

\section{Project IV Reading is Funny}

In order to cultivate the kids' happiness of experiencing reading, it includes below three implementation strategies: establish a exhibiting zone, playing with stories, and dramatic play.

\section{Establish a Zone to Exhibit Their Works of Reading}

It makes young children freely exhibit their works highly interrelated to reading and the activity make every child learn from each other and get closer Therefore, the role of teachers is to help young children to take photos with their own works, which would be able to naturally record their growth and memories. In the zone where kids exhibit their works of reading, we often see kids taking their parents to watch their outcomes.

\section{Listen to and Play with Stories}

The preschool educators could choose a story which young children are familiar with and have been listened for many times. Then, the teacher invites the children to play the game of story marathon or making up stories and Story solitaire. Scaffolding skill here is necessary, for each young child has different characteristic and they have different learning way. Teachers have to set up different activity depends on the story content and in accordance with the children's appropriately learning process toward effective teaching purpose.

\section{Dramatic Play}

There are four steps in implementing dramatic play. In first step, teacher picks up a picture book without context as the script, and use a lot of body movement to descript 
pictures within the book. After generating the turning points and conjunctions of such story based on approach of movement narratives, preschool educators could adopt the rules of moment, such as stop, mechanical movements to inspire kids' interests. For second step, preschool educator could add up voice and language. Teachers can emphasize emotion, points or make up echo, responses or staring to each other, even opposing voices. Another activity which is popular with young children is word puzzle, and it is interesting especially for the combination with the background music which children love. Thirdly, team activities such as teachers telling stories or young children performing stories by groups is very interesting for young children. It not only creates a situation to let kids learn cooperation, emotional regulation, negotiation, expressing, sharing the feelings as performers, and communication within the process of playing, but also learn to be respect others and appropriate interpersonal relationship. Fourthly, the dramatic play could be further combined with preschool graduation ceremony, parents' conference, or children's birthday parties. With teachers' and parents' assistance in putting ordinary picture book stories onto stage, the following steps including picking scripts, letting kids be roles, and preparing relevant tools all lead to unit parents' and teachers' interrelationship.

At last, based on the outcome verification of above four research projects, the research would be able to achieves the spirit of research purpose by daily observation, parents' feedback, researchers' introspection about teaching, adjusting content of search project in accordance with young children's needs and development.

\section{Results and Discussion}

Researchers found the difficulties they encountered while dealing with such solutions. So this chapter is divided into two sections, the first section is the background story of promoting early childhood reading, including difficulties encountered and the efficiency of teachers' promoting children reading; and the second section is to promote early childhood reading with more efficient methods and ways.

The Efficiency of Teachers' Promoting Children Reading

The first section in this chapter means to explain the difficulties during promotion of early childhood reading. By promoting reading in the kindergarten, researchers prepared a suitable and aesthetics environment for reading and tons of learning activities with picture books teaching and extending this form into families. Through promotion of parent-child reading, a continuation of reading, children, parents and teachers all work together and inspire learning objects, among families and schools. This set up a friendly bridge of communication with each other through reading picture books together. In most of kindergarten classes, how to implement parent-child reading becomes the most critical issue. The use of parent-child reading becomes very widely known through library activities, telling story among mother communities, parenting seminars ... etc.

\section{A. Parent-Child Reading at Home}

How to practice parent-child reading at home? The research uses parent-child read together sheets, borrowing books, setting up story-mommy group and speeches for parents...etc. And during the one year, parents' role in participating children's reading serves as cooperator, leader, guider, and share experiences.

To make the distance between parents and children closer, an establishment of parent-child emotional intimacy is a must. With experiences of implementing parent-child reading tried to discover the key for these parents who involved in the process and got an outstanding result. Dickinson, Golinkoff, \& Hirsh-Pasek (2010) [33]pointed out that through discussion, sharing stories, children actively ask questions and express their views. Or it can also be a teacher to ask questions, for everyone to express their personal thoughts. A good question can promote children's logical thinking and problem-solving skills. Let the children be accustomed to thinking independently, and make them have their own views and opinions is good to the formation of their critical thinking skills. As to children's ability to interact with content of picture books or stories and to share each other, by reading, children can learn from the experiences from the others, and they did not forget the correctness of a certain speculative knowledge, therefore they can finally create an inventive thinking for a better future.

Concerning the way educators can do for building warmth atmosphere from classroom to library and to community, action library. The activity style include group, competition, corner, individual discussion, read aloud, reading photos and free play to fresh children's daily reading experience. In order to build reasoning and critical thinking ability, adults could offer children opportunities to think, to talk, to discuss, and to reason, to criticize through the sharing reading activity at home and in preschool. Further, results revealed that there are four elements contributing in successful reading-extension activity.

\section{Environmental Settings}

a. Classroom-settings clearly elaborate children's reading.

b. Aesthetic and multiple reading settings should be combined with community resources and diverse culture content.

\section{Four Activities during Parent-child Reading}

a. Information session in the beginning of the semester.

b. Teacher-designed shared sheets delivered after the reading.

c. Establishment of Story-Mommy group and its interactions with children in the early morning school time.

d. Encouragement of children's participating in take me home (picture books borrowing home) activities 


\section{Teaching Process}

a. "Step by step" progress means far more than the results.

b. The leading children's reading directions should be consistent with the young children's feedback sheets.

c. Aesthetic and beautiful experiences always bring out more internal reading.

d. Teachers' behaviors, words, and deeds strongly influence young children's manner and attitude in reading.

\section{Teachers' Fulfillment in Growth and Self-professionalism}

a. Abundant learning environments benefit the inter-relationship between adults and children.

b. Parents' positive support in shared reading contributes more to the harmony and intense intercourse between parents and teachers.

c. Within shared reading, preschool educators benefit in advancement of reflective ability, theoretical, practical and professional knowledge.

Similar with the research (Kindle, 2011[16]; Willett, Robinson, \& Marsh, 2009[18]), the results of the research revealed that parent-child shared book reading is an indicator of the home literacy environment and is closely related to children's language development. Further, similar with Wasik \& Blewitt (2006)[38] and Lonigan \& Shanahan (2010) [17], the results revealed that the way to effectively promote early childhood reading includes the combination of preschool and family reading. With the one year reading promoting, the research results is similar with Beauhat, Blamey, \& Walpole (2009)[32] research, there are three advantages in teachers' promoting reading: rich learning environment elevates interpersonal relationship, parents' supportive attitude toward promoting reading enhances teachers-children relationship, educators build selfreflection ability in early childhood education professionalism.

\section{The Way of Promoting Children's Reading}

\section{Teacher's Perspective}

Combined with Dewey's (2005)[9] "reflective thinking" "Learning from Doing" concept, the research revealed that teachers' should hold open-mindedness, responsibility, and whole-heartedness in merging attitude and skills, and then transform thinking into reflective actions. Thus, educators should be first of all, love to read, love to enjoy the happiness and pleasure while they are telling stories with children. In preschool learning environment, there are plenty of activities could be merged into story books, including pictures, photos, discussing, playing, role-playing, pretending, music, and art. With arranging multi-cultural and rich aesthetics reading situation, educators need to always self-reflect in finding the most appropriate way in instructing.

\section{Parents' Perspective}

Home, is not only the definition for beautiful house, but also the essence of the members within loving each other. From the research finding, it came to conclusion that parents who would pay the efforts in building children's reading habit would also cultivate children willing to love and read. With parents' loving children, children also learn how to love and to be loved, to think and to reason, to read and to express, to explore and to appreciate. With the correct reading value based on family education, parents encourage children to create reading experience also advance parent-child interrelationship and child-centered learning and development.

\section{Environment Setting Perspective}

With the importance of situation, atmosphere, and environment setting up for young children's learning and playing, environment education lies in aesthetics, warmth, love and easy to reach. The research revealed that picture books need to be reached easily and parents need to be part of reading activity. Unconsciously, reading would become a part of family education and life necessity. Therefore, in preschool, educators should arrange it in a comfortable, love, and warmth situation; at home, parents should be in charge of offering a place for creating aesthetic reading experience for children, including bedroom, living, and library.

\section{From Time Controlling Perspective}

With the advancement of globalization and information technology merged into young children's learning and playing, parents are easy to misuse the computer, i-pad, i-phone, the software equipment...etc for guiding and motivate children learn. However, with Frobel mentioned, with the building of reading habit for young children, this ability will last till adulthood and can't be easily replaced, the research found out that with the habit of quietly reading 10-15 minutes every day would enrich young children's mind and soul. Especially for parent-child reading, the interrelationship between parents and children is positively elevated, and children's development in language, emotional, social, and aesthetics are cultivated. (Beck, McKeown, \& Kucan, 2012 ).[11]

\section{Reading Efficiency Perspective}

When it comes to reading efficiency or performance, it is not about the grades, the speed of reading, but for the children's enjoy in reading. The aesthetics of language, words, photos, pictures, colors, shapes, lines, textures, and rhythms would make young children concentrate and involve in inner motivation reading. It also surprises adults, with the reading seeds inside young children's mind, the gradual growth into little trees would be fulfilled, and with careful and considerate accompany, the little tree would become a big tree.

\section{Recommendations}

From the implementation of parent-child reading and 
parents' storytelling for children in preschool, the researchers successfully promotes reading program and through the continuously recorded process for children, the interviews with parents and teachers, the discover of children's work and the self-reflection in solve problems, the results and suggestions mentioned above hopefully could offer practical ideas for the preschool educators in future promoting preschool reading and parent-child reading. At last, for the adults' role in scaffolding, the research suggests that with adults' passion in reading, listening, telling stories, children would also love to listen, to tell, to communicate, to express, to pretended play, to role play, to fee play, to appreciate, and to think creatively for any story they love. Also, with parents' participating in reading, this is the main reason why children gradually fall in love with literatures. Lingering in a picture book will also increase children's wills to share their feelings to teachers, parents and other children. With the family education perspective, the research also found out that the secret of parent-child reading activities does elevate parent-child interrelationship and further quality family learning environment, the implanting the saplings of reading in children's hearts becomes so easily practiced and fulfilled in early childhood education learning and development.

\section{REFERENCES}

[1] L. Essa. Introduction to Early Childhood Development. London: Cengage Learning, 2012.

[2] M. W. Apple. Education and power. Routledge, 2013.

[3] P. Hallinger, P. Making education reform happen: is there an 'Asian'way?. School Leadership and Management, Vol, 30, No. 5, 401-418, 2010.

[4] N. Heisey \& L. Kucan. Introducing science concepts to primary students through read alouds: Interactions and multiple texts make the difference. The Reading Teacher, Vol, 63, No. 8, 666-676, 2010.

[5] N. Postman The end of education: Redefining the value of school. Vintage, 2011.

[6] P. Race. Making learning happen: A guide for post-compulsory education. Sage, 2014.

[7] Education Bureau. The Grade 1-9 Curriculum Guideline. Retrieved from 2012/03/08. http://teach.eje.edu.tw/9CC2/9cc_97.php, 2008.

[8] Education Bureau. Education Bureau Six Net Learning. Retrieved from https://learning.edu.tw/wp_sixnet/, 2012.

[9] J. Dewey. Art as Experience. Penguin, 2005.

[10] L, Bloom. Becoming a word learner: A debate on lexical acquisition. New York: Oxford University Press, 2010.

[11] I. L. Beck, M. G. McKeown, \& L. Kucan. Bringing Words to Life: Robust vocabulary Instruction. New York: Guilford Press, 2012.
[12] T. Bruce. Early childhood education. Hachette UK, 2012.

[13] S. A. Carlson, J. E. Fulton, S. M. Lee, L. M. Maynard, D. R.. Brown, H. W. Kohl III, \& W. H. Dietz. Physical education and academic achievement in elementary school: data from the early childhood longitudinal study. American Journal of Public Health, Vol, 98, Vol, 4, 721-727, 2008.

[14] D. M. Early, K. L. Maxwell.,M. Burchinal, S. Alva, R. H. Bender, ... \& N. Zill. Teachers' education, classroom quality, and young children's academic skills: Results from seven studies of preschool programs. Child development, Vol, 78, No, 2, 558-580, 2007.

[15] S. E. Mol, A. G. Bus, \& M. T. de Jong. Interactive book reading in early education: A tool to stimulate print knowledge as well as oral language. Review of Educational Research, Vol, 79, No, 2, 979-1007, 2009.

[16] K. J. Kindle. Same book, different experience: A comparison of shared reading in Preschool classrooms. Journal of Language and Literacy Education [Online], Vol, 7, No, 1, 13-34, 2011.

[17] C. J. Lonigan, \& T. Shanahan. Developing early literacy skills: things we know we Know and thing we know we don't know. Educational Researcher, Vol, 39, No,4, 340-346, 2010 .

[18] R. Willett, M. Robinson, \& J. Marsh. Play, creativity and digital cultures. New York, London: Routledge, 2009.

[19] B. A. Wasik, \& M. A. Bond. Beyond the pages of a book: Interactive book reading And Language development in preschool classrooms. Journal of Educational Psychology, Vol, 93, 342-250, 2009.

[20] L. M. McGee, \& D. J. Richgels. Literacy's beginnings: Supporting young readers and Writers. Boston: Pearson, 2008.

[21] L. M. Justice. Word exposure conditions and pre-schoolers' novel word learning During Shared storybook reading. Reading Psychology,Vol, 23, 87-106, 2002.

[22] M. J. Chou, \& H. C. Lee. The application of the iPad on children's play-based on brain science theory. International Journal of Organizational Innovation, Vol, 5, No, 1, 296-308, 2012.

[23] C. H. Ko, \& M. J. Chou. Aesthetics in early childhood education: The combination of technology instruments in children's music, visual arts and pretend play. Journal of Social Sciences, Vol, 10, No, 1, 39-45, 2014.

[24] D. Kassow. Parent Child Shared Book Reading. Talaris Research Institute, Vol, 1, No, 1, 1-9, 2008.

[25] R. A. Sansanelli, \& J. T. Hustedt. The state of preschool 2009: Executive summary. Retrieved from $:<\mathrm{http}: / /$ nieer.org $>$, 2009.

[26] K. E. Wohlwend. Playing their way into literacies: Reading, writing, and belonging in the early childhood classroom. New York: Teachers College Press, 2011.

[27] B. G. Belland, D. Krista, \& C. J. Richardson. Scaffolding Framework to support the construction of evidence-based arguments among middle School students. Education Tech Research Dev., 56, 401-422, 2008. 
[28] J. M. Machado. Early childhood experiences in language arts. Belmont, CA: Wadsworth Cengage Learning, 2010.

[29] T. A. Zucker, A. E. Ward,\& L. M. Justice. Print referencing during read-alouds: A Technique for increasing emergent readers' print knowledge. The Reading Teacher, Vol, 63, No, 1, 62-72, 2009.

[30] A. Biemiller, \& C. Boote. An effective method for building meaning vocabulary in Primary grades. Journal of Educational Psychology, Vol, 98, No, 1, 44-62, 2006.

[31] E. G. Brabham, \& C. Lynch-Brown. Effects of teacher's reading-aloud styles on Vocabulary Comprehension in the Early elementary grades. Journal of Educational Psychology, Vol, 94, No, 3, 465-473, 2002.

[32] K. A. Beauchat, K. L. Blamey, \& S. Walpole. Building preschool children's language and literacy one storybook at a time. The Reading Teacher, Vol, 63, No, 1, 26-39, 2009.

[33] D. K. Dickinson, R. M. Golinkoff, \& K. Hirsh-Pasek. Speaking out for language: Why language is central to reading development. Educational Researcher, Vol, 39, No, 4, 305-310, 2010.

[34] G. Kim. Assessing the Quality of Parent Child Interaction in Shared Reading Using the ICpL. London: ProQuest, 2008.

[35] F. Lellemyr, F. Taking Play Seriously: Children and Play in Early Childhood Education-An exciting challenge. New York: IAP Publisher, 2009.

[36] L. M. Morrow, E. Freitag, \& L. B. Gambrell. Using children's literature in preschool to develop comprehension. Newark, DE: International Reading Association, 2009.

[37] L. S. Vygotsky. Mind in society: The development of higher psychological processes. Cambridge, MA: Harvard University Press, 1978.

[38] B. A. Wasik, \& P. Blewitt. The effect of questioning style during storybook reading On Novel vocabulary acquisition of pre-schoolers. Early childhood education journal, Vol, 33, No, 4, 273-278, 2006.

[39] G. E. Tompkins. Literacy for the 21st Center: Teaching reading and writing in Prekindergarten through grade 4. Upper Saddle River, NJ: Merrill Prentice Hall, 2007.

[40] V. Koshy. Action Research for Improving Educational
Practice: A Step by Step Guide. London: The British Library, 2010

[41] J. A. Schickedanz, \& L. M. McGee. The NELP report of shared story reading Interventions. Extending the story. Educational Researcher, Vol, 39, No, 4, 323-329, 2010.

[42] W. H. Teale, J. L. Hoffman, \& K. A. Paciga.. Where is NELP leading preschool literacy? Instruction? Potential positives and pitfalls. Educational Researcher, Vol, 39, No, 4, 311-315, 2010 .

[43] A. James \& A. Prout. Constructing and reconstructing childhood: Contemporary issues in the sociological study of childhood. Routledge, 2015.

[44] W. J. Lee. The Application of Stories on Leisure Activity. National Taitung University. Unpublished Thesis, 2002.

[45] Y. L. Liao. Give me Five-enjoy reading. China Early Childhood Education, Vol, 301, 26-41, 2011.

[46] G. J. Huang. Research on Primary $6^{\text {th }}$ Grade Students' Reading Interests. National Taitung University. Unpublished Thesis, 2004.

[47] M. H. Lin. Reading Symposium-Play on reading in classroom. National Taitung University. Unpublished Thesis, 2004.

[48] C. H. Ko. The Interest of Parent-Child Reading. Health Magazine Kids Section, Vol. 2, 154-159, 2003.

[49] C. Y. Liao. Life Education of Reading. Taipei: World Magazine, 2011.

[50] Y. L. Liao. Exploration on Children's Reading Practice. National Taitung University. Unpublished Thesis, 2008.

[51] S. C. Dun. Action Research on Preschool Educators' Promoting Reading. National Taitung University. Unpublished Thesis, 2008.

[52] C. W. Liao. Research on Cultivating Children's Reading Habit. Hung-Guon Technology University 2008 Language and Teaching International Conference, 2008.

[53] W. L. Lin. Magic on Silent Revolution-Action Research on Preschool's Parent-Child Reading. National Tun-Hwa University. Unpublished Thesis, 2009. 